Scientia Marina 83(1)

March 2019, 19-30, Barcelona (Spain)

ISSN-L: 0214-8358

https://doi.org/10.3989/scimar.04804.22C

\title{
Comparative study of skipjack tuna Katsuwonus pelamis (Scombridae) fishery stocks from the South Atlantic and western Indian oceans
}

\author{
Lol I. Dahlet ${ }^{1,2}$, Nicola Downey-Breedt ${ }^{3}$, Gabriel Arce ${ }^{1}$, Warwick H.H. Sauer ${ }^{3}$, \\ Maria A. Gasalla ${ }^{1,4}$ \\ ${ }^{1}$ Fisheries Ecosystems Laboratory (LabPesq), Oceanographic Institute, University of São Paulo. 191, Praça do \\ Oceanográfico, Cidade Universitária, São Paulo (SP), Brazil. \\ (LID)(Corresponding author) E-mail: 1.dahlet@ hotmail.com. ORCID iD: https://orcid.org/0000-0003-1743-852X \\ (GA) E-mail: arceiousp@gmail.com. ORCID iD: https://orcid.org/0000-0002-6514-3163 \\ (MAG) E-mail: mgasalla@usp.br. ORCID iD: https://orcid.org/0000-0003-1506-7040 \\ ${ }^{2}$ Current address: Graduate Programme in Sustainable Fisheries Management, University of Alicante, Spain. \\ ${ }^{3}$ Department of Ichthyology and Fisheries Science, Rhodes University, Prince Alfred street PO Box 94, 6140 \\ Grahamstown, South Africa. \\ (ND-B) E-mail: nicola.breedt@ gmail.com. ORCID iD: https://orcid.org/0000-0001-6152-9424 \\ (WHHS) E-mail: w.sauer@ru.ac.za. ORCID iD: https://orcid.org/0000-0002-9756-1757 \\ ${ }^{4}$ Institute of Advanced Studies (IEA), University of São Paulo, 513 Rua do Anfiteatro, Cidade Universitária, \\ São Paulo (SP), Brazil.
}

\begin{abstract}
Summary: The skipjack tuna, Katsuwonus pelamis, inhabits tropical and subtropical oceans the world over, and contributes substantially to total tuna catches. Both fishing pressure and anthropic influences affect skipjack populations, impacting on economic returns and investment. The present study analyses and compares spatial time series of catch and catch per unit effort (CPUE), of pole-and-line fishing of skipjack tuna from Brazil, South Africa and the Maldives. Both regional and interregional analyses were conducted for the period 1970-2014 in order to ultimately investigate potential associations between these fisheries, climatic conditions and the El Niño Southern Oscillation (ENSO). Correlation tests and spatial mapping tools were used. From 2004 to 2011, South African skipjack catches correlated positively with Brazilian ones and negatively with Maldivians. CPUEs from the Brazilian and Maldivian skipjack fisheries showed a significant positive correlation in the period 1982-1993. Yearly catches from all regions were strongly associated with the Northern Oscillation Index $(\mathrm{p}<0.001)$, an ENSO index. This study reflects an effort to articulate an inter-regional appraisal of skipjack pole-and-line fisheries embedded in the context of a globally changing climate, in the face of which emerging economies are the most vulnerable. Evidence of common patterns influencing these fisheries should encourage international South-South cooperative management and understanding of the resource.
\end{abstract}

Keywords: oceanic fisheries; inter-regional oceans; ENSO; teleconnections; tRFMOs; bonito.

Estudio comparativo de los recursos pesqueros de bonito listado Katsuwonus pelamis (Scombridae) de los océanos Atlántico Sur e Índico Oeste

Resumen: El listado, Katsuwonus pelamis, habita los océanos tropicales y subtropicales del mundo, y contribuye substancialmente a la captura total de la flota atunera. Sus poblaciones son afectadas por la presión pesquera e influencia antrópica, impactando en el rendimiento económico e inversiones. El presente estudio analiza y compara series temporales de captura y captura por unidad de esfuerzo (CPUE) de las pesquerías de línea de mano y caña de Brasil, Sudáfrica y Maldivas. Se han realizado análisis regionales e inter-regionales para el periodo 1970-2014 a fin de investigar potenciales asociaciones entre estas pesquerías, condiciones climáticas y el fenómeno de la Oscilación del Sur - El Niño (ENSO), habiéndose empleado tests de correlación y herramientas de mapeo. Entre 2004 y 2011, las capturas sudafricanas de bonito listado correlacionan positivamente con las brasileñas, y negativamente con las maldivas. Las CPUEs de las pesquerías de Brasil y Maldivas demostraron una correlación positiva para el periodo 1982-1993. Las capturas anuales para todas las regiones resultaron fuertemente relacionadas con el Indice de Oscilación del Norte (NOI) (p<0.001), un índice de ENSO. Este estudio refleja un esfuerzo para articular una evaluación de la pesquería de línea y caña del listado en el contexto de un clima cambiante, frente a lo cual las economías emergentes son las más vulnerables. Al poner en evidencia pautas de influencias comunes a estas pesquerías, se espera fomentar la cooperación internacional Sur-Sur para un manejo y comprensión de las dinámicas del recurso.

Palabras clave: pesca oceánica; océanos inter-regionales; ENSO; teleconexiones; ORPs; listado.

Citation/Como citar este artículo: Dahlet L.I., Downey-Breedt N., Arce G., Sauer W.H.H., Gasalla M.A. 2019. Comparative study of skipjack tuna Katsuwonus pelamis (Scombridae) fishery stocks from the South Atlantic and western Indian oceans. Sci. Mar. 83(1): 19-30. https://doi.org/10.3989/scimar.04804.22C 
Editor: V. Stelzenmüller.

Received: May 14, 2018. Accepted: February 11, 2019. Published: March 6, 2019.

Copyright: $\odot 2019$ CSIC. This is an open-access article distributed under the terms of the Creative Commons Attribution 4.0 International (CC BY 4.0) License.

\section{INTRODUCTION}

Temporal and spatial fluctuations in the abundance of oceanic pelagic populations spread geographically around the globe are common (Cushing 1975). The causes of these fluctuations may be exogenous (environmental or anthropogenic) or endogenous to the organism (e.g. ontogenetic drivers) (Ricker 1954). This scenario applies to some tuna stocks, including the skipjack tuna, Katsuwonus pelamis (Linnaeus, 1758), known as bonito-listrado in Brazil, katunkel, or ocean bonito in South Africa, and godhaa (bigger) or kadumas (smaller) skipjack in the Maldives.

The skipjack belongs to the family Scombridae and inhabits tropical and subtropical areas of the globe. On average, $85 \%$ of skipjack catch occurs in waters warmer than $24^{\circ} \mathrm{C}$ (Fonteneau 2003). This resource is of particular importance, accounting for $57 \%$ of the global industrial tuna catch in 2016, and is mainly processed by the canning industry. Skipjack catches totalled 2.79 million $t$ in 2016 (ISSF 2018), and currently $8.5 \%$ of worldwide catches are made by the pole-andline fleet. In Brazil and the Maldives, the resource is well-known. Catches in Brazil were seen to increase until 2014, while in the Maldives, 2006 marked the beginning of a strong and unsettling decline that continued until recent years. Off South Africa, skipjack catches are 1000 to 10000 times lower than those from Brazil and the Maldives, and the highest catches were recorded in 2012.

In Brazil, this fishery began in Rio de Janeiro in 1978 , and today the Brazilian southeastern coast hosts strategic spots at both the global and national scales. The fishery here is considered sustainable, although it is not officially certified as such, and it accounts for $10.2 \%$ of total Atlantic skipjack catch (ICCAT 2017). Purse-seine fleets dominate the skipjack fishery in the eastern Atlantic Ocean, where catches are seven-fold higher than those in the western Atlantic Ocean. In the eastern Atlantic, fishing is concentrated between $20^{\circ} \mathrm{N}$ and $25^{\circ} \mathrm{S}$. Skipjack catches have been recorded since the 1960s off Namibia, composing a fraction of the $55.6 \mathrm{t}$ of mackerels, tunas and bonitos caught in the region in 1978, and totalling only $0.01 \mathrm{t}$ in 2014 (Belhabib et al. 2016). South African tuna fisheries have no fleet specifically targeting skipjack tuna and therefore no effort directed towards it; it is caught as bycatch.

Unlike the Brazilian and South African fisheries, the Maldivian skipjack fishery is well developed and regulated, accounting for $16 \%$ of the total catch (446723 t) within the Indian Ocean (IOTC 2017). The Maldivian pole-and-line skipjack fishery has been certified as sustainable by the Marine Stewardship Council since 2012 (MoFA 2013), while the yellowfin tuna pole-andline fishery is presently suspended. Despite the market demand for canned and frozen tuna, the Maldives skipjack caught by regional fleets are mainly earmarked to be traded and consumed locally (IOTC 2017).

The current study is part of an international multilateral research initiative aimed at planning climate change adaptation in marine warming hotspots of the Southern Hemisphere (Popova et al. 2016). Several studies have analysed catch, effort and catch and effort time series related to skipjack fisheries in the southwestern Atlantic (Andrade 2003, Meneses de Lima 2006), the east Atlantic (Fonteneau 1986) and the Indian Ocean (Ménard et al. 2000, Adam and Sibert 2002, Dueri et al. 2014). Climatic conditions such as temperature and its variation not only affect the global distribution of this resource (Arrizabalaga et al. 2014), but also the fishers' strategies. For example, Andrade et al. (2005) show that days with rain tend to decrease skipjack CPUE in the southwest Atlantic. On a larger scale, atmospheric and sea surface temperature are periodically shaped by large-scale climatic phenomena such as the El Niño Southern Oscillation (ENSO) (Dong et al. 2006). These large-scale climate anomalies result in physical and biological impacts in oceanic regions, which can in turn affect ecosystems on a more local level. Decreases in catch and catch rates in the Maldivian skipjack fisheries during ENSO years are addressed by Hafiz and Anderson (1994) and Kumar et al. (2014). However, El Niño impacts on the Brazilian skipjack fisheries have yet to be investigated, and nor has a recent comprehensive interocean comparison across these three areas been undertaken. With climate and ocean conditions in these basins highly interconnected (Nicholson 1997), such an inter-ocean comparison is important. The Brazilian and Maldivian fisheries are of primary importance in their home countries, particularly as emerging or developing nations potentially face greater vulnerability from climate change effects on fisheries (Allison et al. 2009). Therefore, understanding how teleconnections can impact commercially important fish stocks helps to formulate hypotheses on how they may be influenced by potential climate variations, and to anticipate challenges and opportunities.

This study aimed to review pole-and-line fisheries data of skipjack Katsuwonus pelamis sub-stocks from the southwestern and southeastern Atlantic Ocean, and from the Maldives in the western Indian Ocean. Intra and inter-annual similarities and discrepancies were explored for the periods 1981-1993 and 2004-2011 by investigating time series of skipjack catches in the three areas studied and catch per unit effort (CPUE) off the southeastern Brazilian coast and the Maldives. Space-time variation of the geographic location of fishery events was also addressed, including a possible association with regional atmospheric temperature 


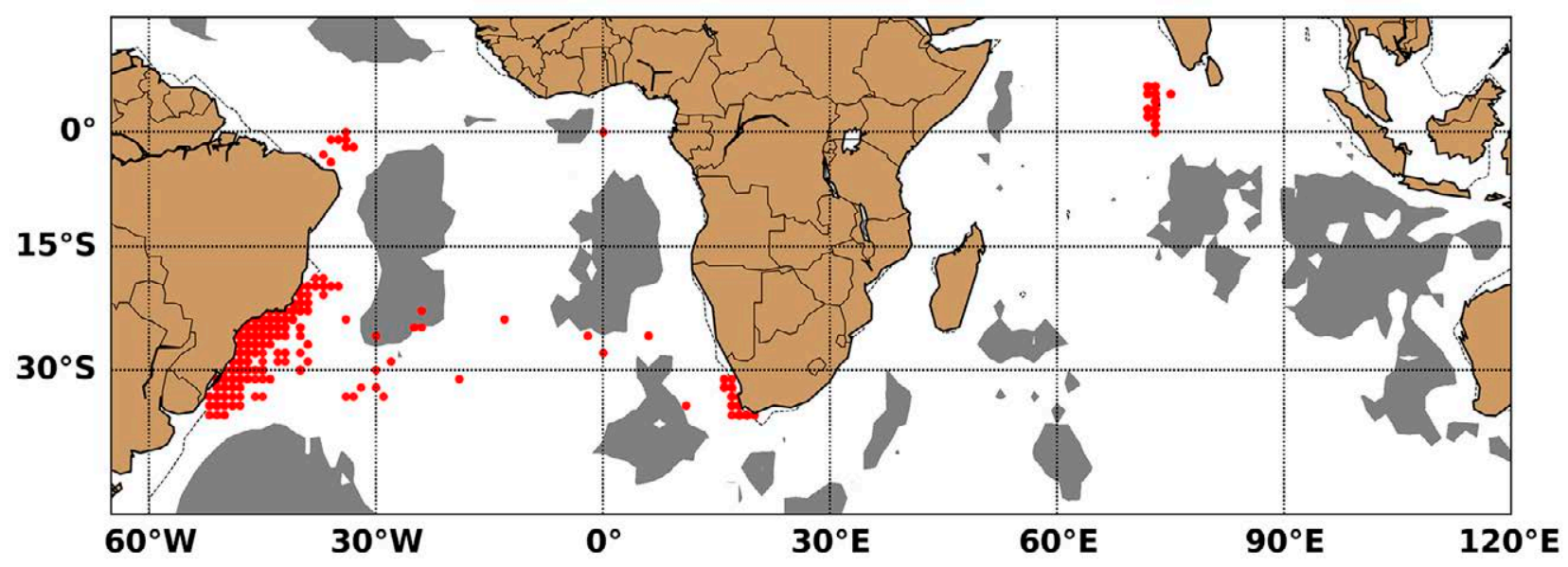

Fig. 1. - Pole-and-line skipjack fishing events (in red) off BR, SA and the MA (data sourced from ICCAT 2014a, IOTC 2016). The dotted line indicates the $200 \mathrm{~m}$ isobaths; the grey areas correspond to depths greater than $4000 \mathrm{~m}$.

and rainfall patterns. Finally, we explore the potential influence of El Niño and/or La Niña events on skipjack catches.

\section{MATERIALS AND METHODS}

\section{Study areas and data}

The three study areas: (i) the southwestern Atlantic Ocean (SWAO), (ii) the southeastern Atlantic Ocean (SEAO) and (iii) the western Indian Ocean (WIO) are shown in Figure 1. The descriptions and boundaries of the study areas follow.

(i) The SWAO is demarcated by a rectangle from $10^{\circ} \mathrm{S}$ to $40^{\circ} \mathrm{S}$ and $29^{\circ} \mathrm{W}$ to $60^{\circ} \mathrm{W}$. This area corresponds to Brazil's southeastern coast, where we considered a Brazilian sub-stock (from now on referred to as BR). This delimitation covers statistical area 41 outlined by the Food and Agriculture Organization of the United Nations (FAO), and also corresponds to the 'Southwest Atlantic' compartment suggested by the International Commission for the Conservation of Atlantic Tunas (ICCAT). The oceanic circulation pattern in this region is dominated by the Brazil Current and the BrazilMalvinas confluence (or Subtropical Convergence, around 33-38 ${ }^{\circ}$ ) (Campos et al. 1995). Catch, Effort and geographic coordinates of the fishing events were taken from the ICCAT online database 'Task II - Catch and Effort' (T2CE) (consulted 4 February 2016). The time series covered three separate periods. The first set of data encompassed 1981-1999; the second 20012011; and the third 2013-2014. Data with zero catch and a positive effort were considered, while blank catch and effort records were removed. Thus, 5819 data records were used for the Brazilian analysis.

(ii) The SEAO was defined as the area encompassed by latitudes $25^{\circ} \mathrm{S}$ and $40^{\circ} \mathrm{S}$, and the meridians $05^{\circ} \mathrm{E}-30^{\circ} \mathrm{E}$. Fishing effort is concentrated in the vicinity of the Benguela Current Large Marine Ecosystem as far north as $20^{\circ} \mathrm{S}$ (ICCAT 2014b). Data for skipjack incidentally caught by the pole-and-line fleet off South Africa (from now on referred to as SA) targeting the Thunnus albacares (yellowfin tuna) were used. Catch data and geographic coordinates of the fishing events were provided by the South African Department of Agriculture, Forestry and Fisheries. There were no effort data for this region. The time series encompassed the period 2003-2013, with no data for the months from July to September. A total of 1513 records were analysed.

(iii) The WIO was delimited by the Equator and the $45^{\circ} \mathrm{S}$ latitude, and the longitudes ranging from $20^{\circ} \mathrm{E}$ and $80^{\circ} \mathrm{E}$; north of the Equator, the study area reached the $77^{\circ} \mathrm{E}$ longitude and the northern limit is imposed by the Asiatic continent. This cut-out is the same as that adopted by the Indian Ocean Tuna Commission (IOTC) and coincides with statistical area 51 of the FAO. As pole-and-line skipjack catches in this region are almost exclusively caught by the Maldivian fleet (MPHRE 2016) and the Indian fleet is active in a smaller area $\left(5^{\circ} \mathrm{N} ; 72.5^{\circ} \mathrm{E}\right)$ and for specific years only, the present study considered only catch data from the Maldivian skipjack fishery (hereafter referred to as MA). Data were sourced from the IOTC online database 'IOTC-2016-DATASETS-CESurface' (consulted 4 February 2016). A total of 9412 records of catch, effort and geographic coordinates of the fishing events were analysed. The MA time series covered the periods 1970-1993 and 2004-2014.

Air temperature (in ${ }^{\circ} \mathrm{C}$ ) and rainfall (in $\mathrm{mm}$ ) data for Brazil, South Africa and the Maldives were downloaded from the Climate Change Knowledge Portal for Development Practitioners and Policy Makers. The dataset is made available online (http://sdwebx. worldbank.org/climateportal/index.cfm) (consulted 3 November 2018) by the World Bank Group and includes climate and seasonality baselines by country, year and month.

\section{Inter-annual and seasonal analysis}

Inter-annual and seasonal comparisons were carried out through the R-studio software for annual total catches reported in the three areas, while the median CPUE was calculated for the BR and MA stocks only. Annual total catch was defined as the sum of all catches 
in $\mathrm{t}$. The median CPUE was estimated as the median of each CPUE. For BR CPUE analysis, the year 1981 was not included, as CPUE for this year was given in t per effective fishing day, which differed from the rest of the data set (given in t per fishing day). This calculation was made for each record of a given year (inter-annual analysis) and for the records of each month of every year (seasonal analysis) in order to plot the respective yearly and monthly catch series.

We first verified the yearly tendencies, adjusting a linear function and obtaining the adjusted R-squared (using Ezekiel 1930 cited in Legendre et al. 2011) for the periods of time in accordance to the available sets of data. The BR time series was divided into three periods, and two linear regressions were adjusted: one for the period 1981-1999 and the other for 2001-2011 and 2013-2014 combined. For the MA and SA data, a linear regression was applied for each data period. The Spearman coefficient was chosen to measure the association between the time series of catch, CPUE, temperature and rainfall for both annual and monthly analysis between the three regions.

\section{Space-time distribution}

Inter-annual and seasonal maps were plotted to analyse the space-time fluctuations of catch and CPUE. Since the geographic seasonality of the average quarterly catch off Brazil and the Maldives is very analogous to the CPUE distribution, and the SA plot did not show significant trends in terms of distribution of fishing activity, only data for space-time distribution of Brazil and MA's CPUE are subsequently presented. We used the ggmap (Kahle and Wickham 2013) and mapproj (McIlroy 2015) packages in Rstudio. The geographic coordinate records within the data sets were grouped in statistical squares of $1^{\circ} \times 1^{\circ}$ (for all the study regions); $5^{\circ} \times 5^{\circ}$ for the MA and BR regions; and $10^{\circ} \times 10^{\circ}$ (for the $\mathrm{BR}$ region).

\section{El Niño Southern Oscillation}

The occurrence of the global ENSO climatic event was compared with the mean yearly catches. The Northern Oscillation Index (NOI) time series, used as an indicator of ENSO, was sourced online from the Climate Prediction Centre of the National Oceanic and Atmospheric Administration through its ERDDAP data server (available at https://upwell. pfeg.noaa.gov/erddap/info/erdlasNoix/index.html, variable "noix") (consulted 24 October 2018). The index reflects the variability in equatorial and extratropical teleconnections and represents a wide range of local and remote climate signals (Schwing et al. 2002). A negative NOI indicates the occurrence of El Niño, while the opposite is associated with La Niña. Median yearly catch values were calculated for the time series and then plotted against the NOI indices for the same year, based on the methodology proposed by Ormaza-González et al. (2016). Polynomial regression curves were obtained using locally estimated scatterplot smoothing (LOESS),

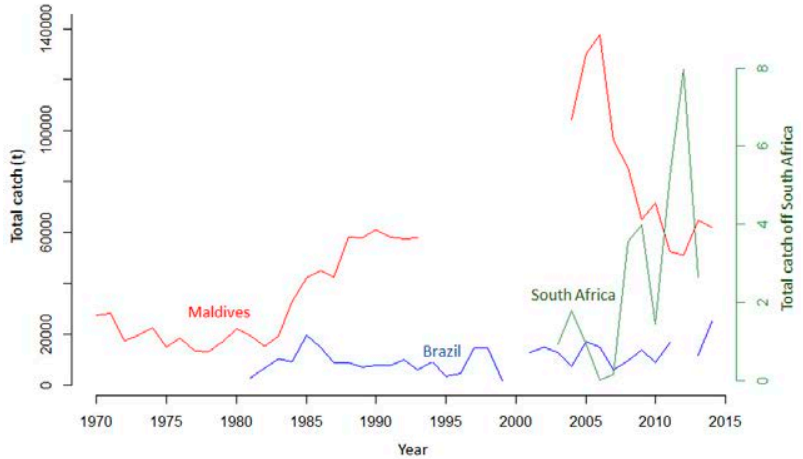

Fig. 2. - Annual total catches in $\mathrm{t}$ for BR, MA and SA skipjack fisheries.

and R-squared values were calculated from the curve parameterization. We then investigated potential correlation between the catch and the NOI signal for each studied region through Spearman coefficient calculation.

\section{RESULTS}

\section{Inter-annual analysis}

Catch

Figure 2 shows a plot of the total skipjack catches for each region. Off the South Brazil shelf, total skipjack catches increased by about 700\% from 1981 to 1985. Thereafter, values fluctuated around $8000 \mathrm{t}$, with a peak in 2014. Although no correlation was found ( $r s=0.17, p<0.05)$, the BR and SA time series visually displayed similar behaviours from 2007 onwards, i.e. an increase in catches from 2007-2009, followed by a drop in 2010, and again an increase in the following year. In the SA region, catches were 1000 to 10000 times lower than those recorded in $\mathrm{BR}$ and MA. The catch data for MA showed a general increase in 1970-1993 $\left(\mathrm{R}^{2}=0.66\right)$, with the highest catches (137 $535.37 \mathrm{t}$ ) recorded in 2006, followed by

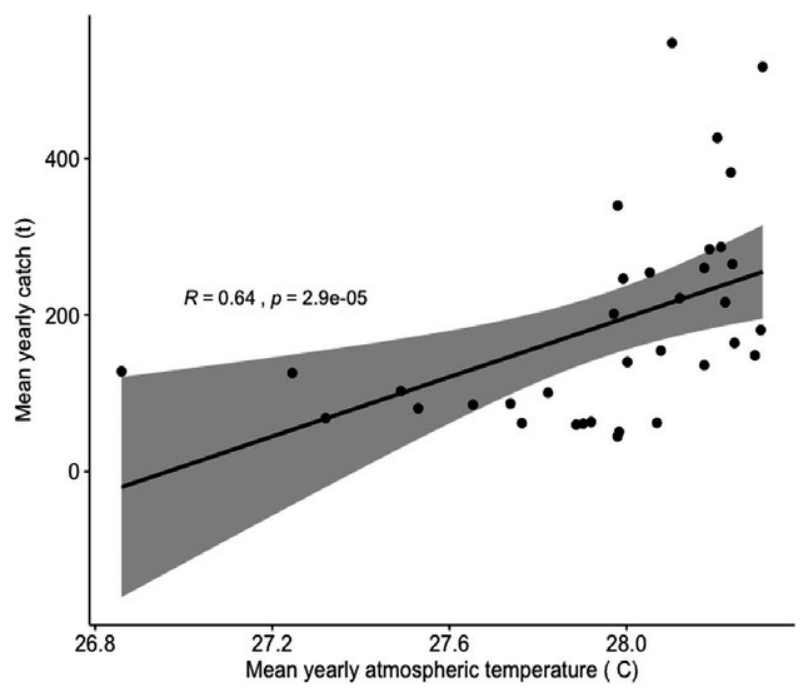

Fig. 3. - Mean yearly skipjack catch as a function of the atmospheric temperature in the Maldives for 1970-2014. 


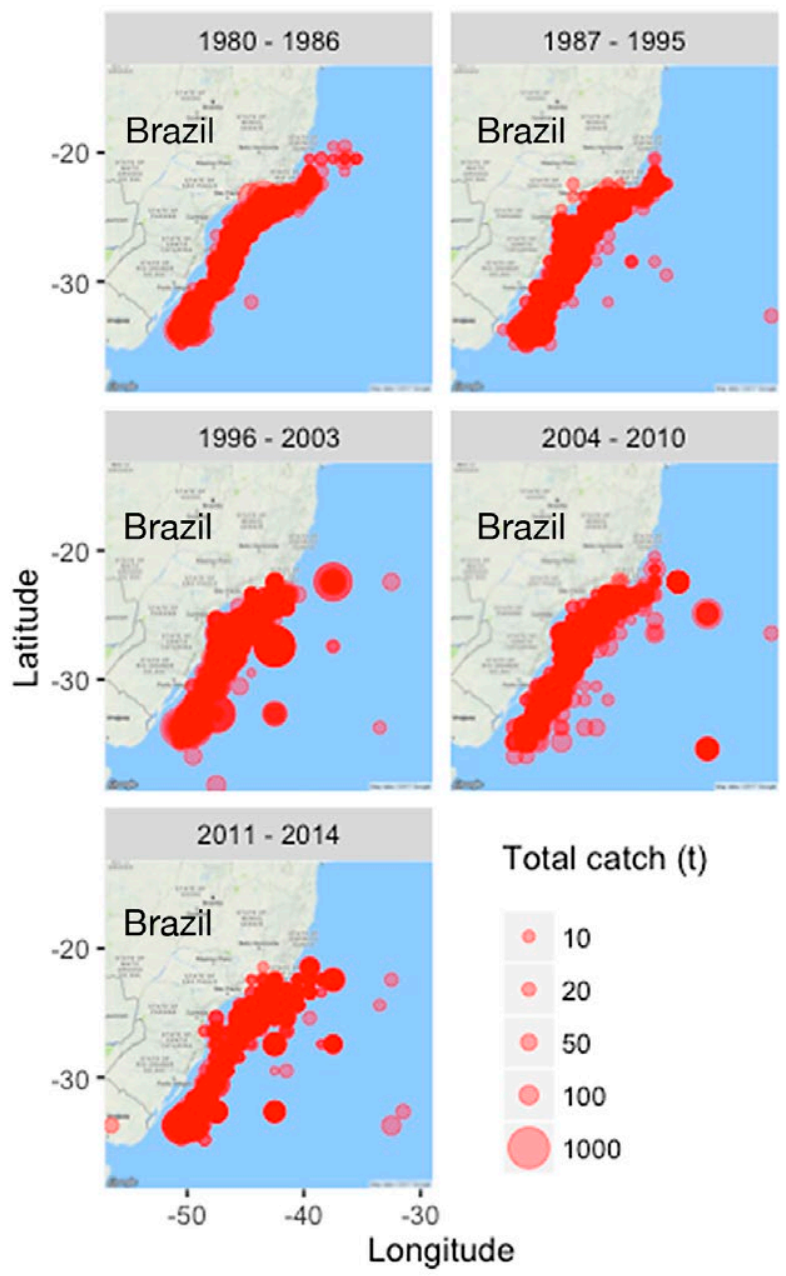

Fig. 4. - Space-time distribution of the total catch by time period off southeast BR. A stronger or lighter red colouration indicates the density of the point cloud.

a general decreasing trend $\left(\mathrm{R}^{2}=0.67\right)$. Spearman coefficient analysis showed a strong negative correlation between the MA and SA skipjack catches between 2004 and 2011 only ( $r s=-0.833, \mathrm{p}<0.05)$. Regarding climate data, both BR and MA showed a clear trend of rising temperatures $\left(\mathrm{R}^{2}=0.749\right.$ and $\mathrm{R}^{2}=0.625$, respectively) over the years. Only the Maldives mean yearly skipjack catch displayed a significant positive association with the region's mean temperature $(r s=0.645$, $\mathrm{p}=2.91 \mathrm{e}-5)$ (Fig. 3).

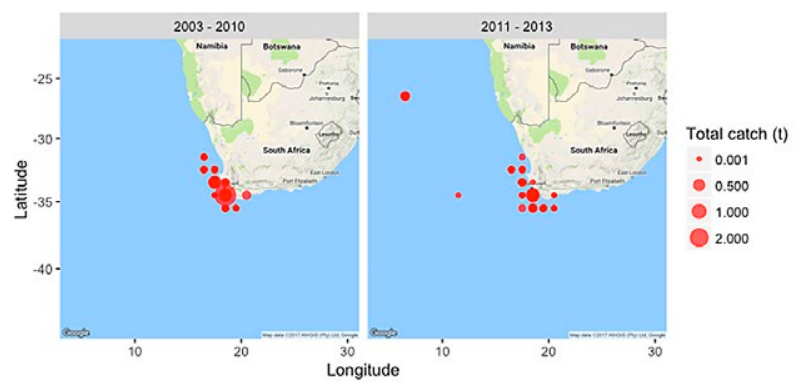

Fig. 5. - Space-time distribution of the total catch by time period off SA.

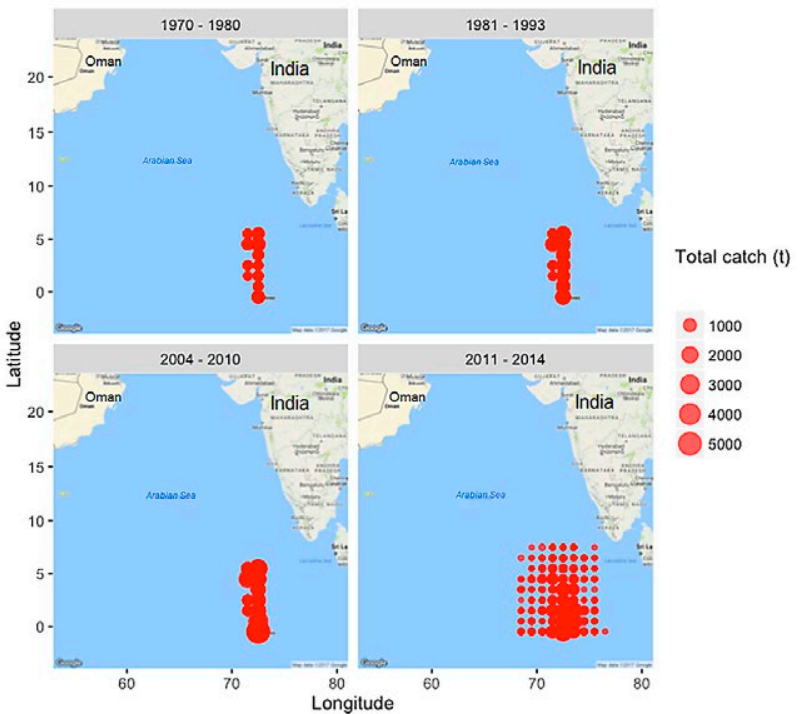

Fig. 6. - Space-time distribution of the total catch by time period in the Maldives.

\section{Space-time distribution}

Between 1980 and 1995, the distribution of skipjack catches in BR (Fig. 4) did not appear to vary significantly: fishing was concentrated between latitudes $32.5^{\circ} \mathrm{S}$ and $33.5^{\circ} \mathrm{S}$. In $1996-2003$, isolated catches higher than $1000 \mathrm{t}$ were evident. Over time, the point cloud gets thicker and pulls away from the coast.

Off South Africa, fishing remained located off the west coast during both periods analysed, in the vicinity of False Bay (Fig. 5). Interestingly, skipjack has also been caught further offshore in recent years (2011-2013).

In MA (Fig. 6), between 1970 and 2010, fishing activity was performed in a narrow belt between $70^{\circ}$ and $74^{\circ}$ longitude. In more recent years (2011-2014), although the latitudinal distribution of fishing activity remained the same, the fishing area appears to have expanded further west and east.
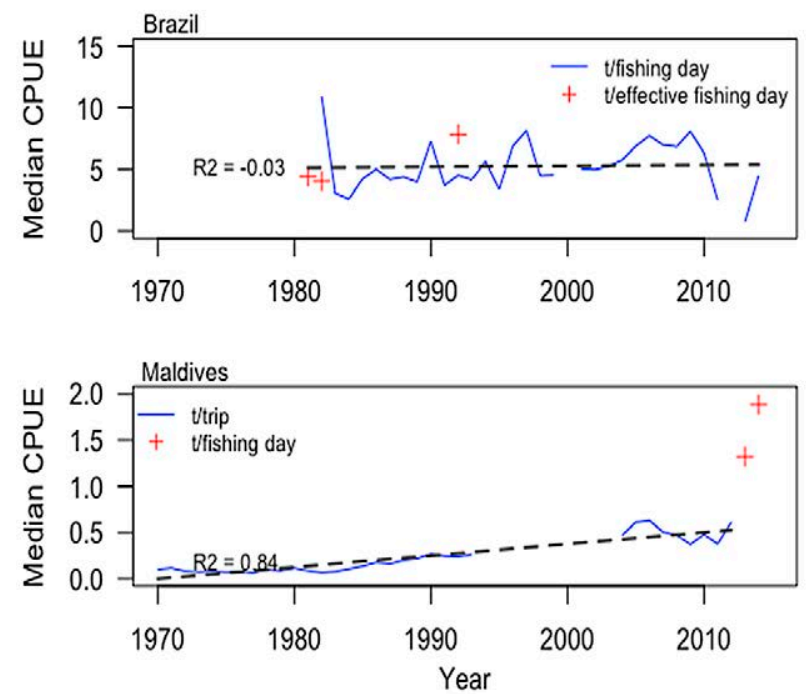

Fig. 7. - Annual median CPUE per studied region. 

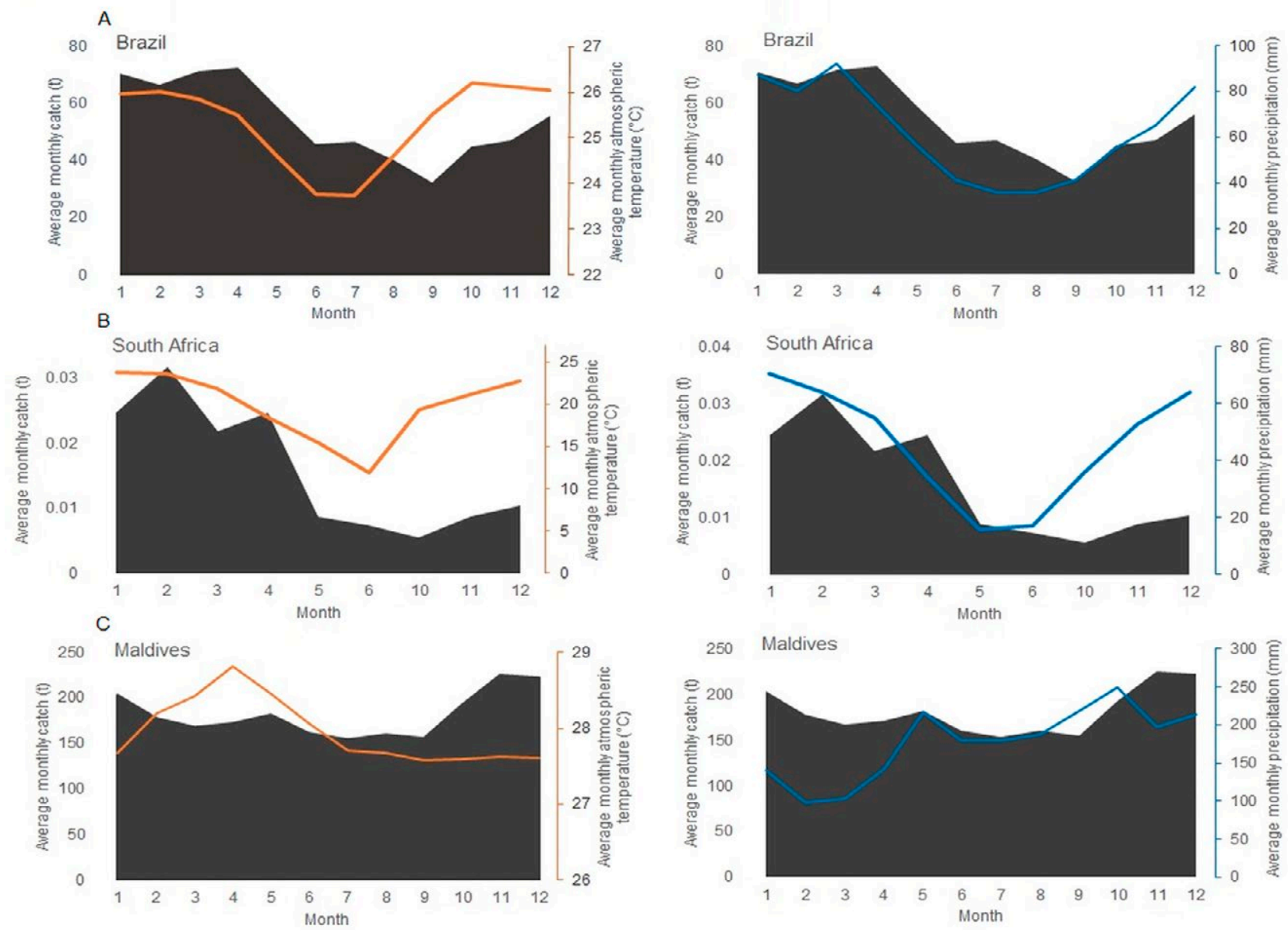

Fig. 8. - Average monthly skipjack catch (in t) in Brazil (A), South Africa (B) and the Maldives (C), overlapped by the average monthly temperature (in ${ }^{\circ} \mathrm{C}$, orange curve), and the average monthly precipitation (in $\mathrm{mm}$, blue curve).

\section{Catch per unit effort}

Figure 7 shows the median CPUE time series data for BR and MA. Values varied between 0 and $11 \mathrm{t} / \mathrm{fish}$ ing day or t/effective fishing day in BR; and between 0 and $2 \mathrm{t} /$ trip or $\mathrm{t} /$ fishing day in MA.

There was considerable fluctuation of CPUE throughout the BR time series, and the corresponding adjusted
$R$-square was low and non-significant $(\mathrm{p}=0.85)$. In the Maldives, the highest CPUE occurred in 2006, prior to a decline until 2009. The data suggest that over the entire period there has been a gradual increase in CPUE since 1970: a linear model showed reasonable adjustment (pvalue of around $10^{-14}$ ). Median CPUE values were positively correlated between 1982 and 1993: the Spearman coefficient was $0.594(\mathrm{p}=0.023)$.

Table 1. - Spearman correlation coefficient calculated between both yearly and monthly average catch (t), air temperature $\left({ }^{\circ} \mathrm{C}\right)$ and rainfall $(\mathrm{mm})$, in the three studied area. The asterisk indicates significant correlation.

\begin{tabular}{|c|c|c|c|}
\hline Brazil & $\begin{array}{c}\text { Yearly } \\
\text { Mean catch }(\mathrm{t}) \\
\text { Mean air temperature }\left({ }^{\circ} \mathrm{C}\right)\end{array}$ & $\begin{array}{l}\text { Mean air temperature }\left({ }^{\circ} \mathrm{C}\right) \\
\mathrm{rs}=0.346 \mathrm{p}=0.0530\end{array}$ & $\begin{array}{l}\text { Mean rainfall }(\mathrm{mm}) \\
\mathrm{rs}=0.346 \mathrm{p}=0.0533 \\
\mathrm{rs}=-0.183 \mathrm{p}=0.314\end{array}$ \\
\hline & $\begin{array}{c}\text { Monthly } \\
\text { Mean catch }(\mathrm{t}) \\
\text { Mean air temperature }\left({ }^{\circ} \mathrm{C}\right)\end{array}$ & $\begin{array}{l}\text { Mean air temperature }\left({ }^{\circ} \mathrm{C}\right) \\
\text { rs }=0.140 \mathrm{p}=0.667\end{array}$ & $\begin{array}{c}\text { Mean rainfall }(\mathrm{mm}) \\
\mathrm{rs}=0.804 * \mathrm{p}=0.003 \\
\mathrm{rs}=0.573 \mathrm{p}=0.055\end{array}$ \\
\hline \multirow[t]{2}{*}{ South Africa } & $\begin{array}{c}\text { Yearly } \\
\text { Mean catch }(\mathrm{t}) \\
\text { Mean air temperature }\left({ }^{\circ} \mathrm{C}\right)\end{array}$ & $\begin{array}{l}\text { Mean air temperature }\left({ }^{\circ} \mathrm{C}\right) \\
\text { rs }=0.582 \mathrm{p}=0.066\end{array}$ & $\begin{array}{l}\text { Mean rainfall }(\mathrm{mm}) \\
\mathrm{rs}=-0.345 \mathrm{p}=0.299 \\
\mathrm{rs}=-0.255 \mathrm{p}=0.451\end{array}$ \\
\hline & $\begin{array}{c}\text { Monthly } \\
\text { Mean catch }(\mathrm{t}) \\
\text { Mean air temperature }\left({ }^{\circ} \mathrm{C}\right)\end{array}$ & $\begin{array}{l}\text { Mean air temperature }\left({ }^{\circ} \mathrm{C}\right) \\
\text { rs }=0.617 \mathrm{p}=0.086\end{array}$ & $\begin{array}{c}\text { Mean rainfall }(\mathrm{mm}) \\
\mathrm{rs}=0.533 \mathrm{p}=0.148 \\
\mathrm{rs}=0.967 * \mathrm{p}=1.7 \mathrm{e}-4\end{array}$ \\
\hline \multirow[t]{2}{*}{ Maldives } & $\begin{array}{c}\text { Yearly } \\
\text { Mean catch }(\mathrm{t}) \\
\text { Mean air temperature }\left({ }^{\circ} \mathrm{C}\right)\end{array}$ & $\begin{array}{l}\text { Mean air temperature }\left({ }^{\circ} \mathrm{C}\right) \\
\mathrm{rs}=0.645^{*} \mathrm{p}=2.91 \mathrm{e}-5\end{array}$ & $\begin{array}{l}\text { Mean rainfall }(\mathrm{mm}) \\
\mathrm{rs}=-0.151 \mathrm{p}=0.386 \\
\mathrm{rs}=-0.066 \mathrm{p}=0.705\end{array}$ \\
\hline & $\begin{array}{c}\text { Monthly } \\
\text { Mean catch }(\mathrm{t}) \\
\text { Mean air temperature }\left({ }^{\circ} \mathrm{C}\right)\end{array}$ & $\begin{array}{l}\text { Mean air temperature }\left({ }^{\circ} \mathrm{C}\right) \\
\mathrm{rs}=-0.182 \mathrm{p}=0.573\end{array}$ & $\begin{array}{c}\text { Mean rainfall }(\mathrm{mm}) \\
\mathrm{rs}=0.133 \mathrm{p}=0.683 \\
\mathrm{rs}=-0.601 \mathrm{p}=0.043\end{array}$ \\
\hline
\end{tabular}




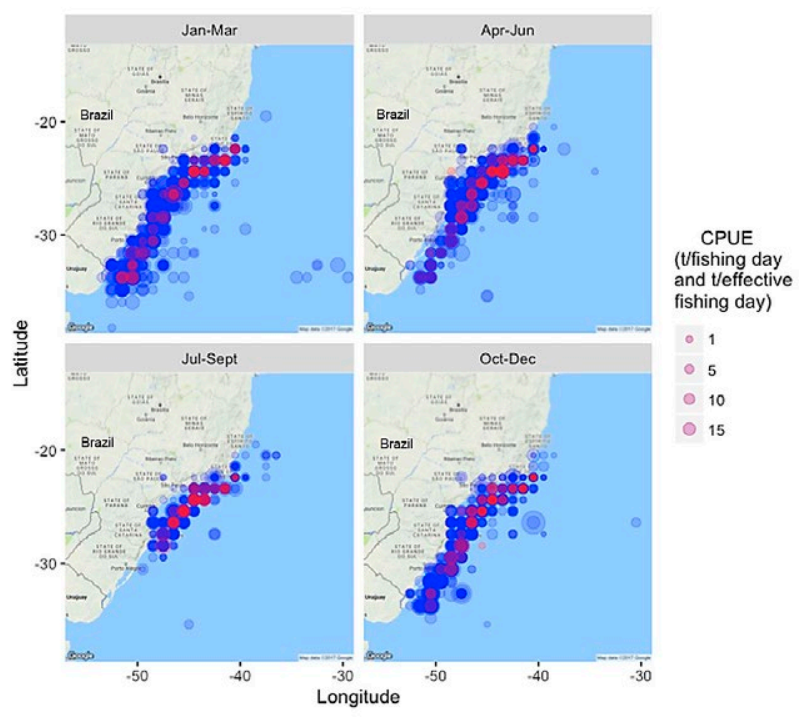

Fig. 9. - Quarterly maps of the total CPUE off Brazil (units: in blue t/fishing day; in red t/effective fishing day).

\section{Seasonal analysis}

\section{Catch}

Off Brazil, catches were higher during summer and autumn (January to May) (Fig. 8A), with the lowest catches occurring two months after the lowest mean temperature $\left(24^{\circ} \mathrm{C}\right)$ and rainfall $(40 \mathrm{~mm})$ were recorded. This association is supported by the significant Spearman correlation found among these variables (Table 1). Climatic data for South Africa (Fig. 8B) follow the very same pattern as those of Brazil, and so do skipjack catches, which also peaked in summer. The Spearman coefficient was $0.883(\mathrm{p}<0.05)$, indicating a positive correlation between monthly catches of both regions (except for the months July to September).

However, in MA (Fig. 8C) catches were higher during months 11 and 12, when temperatures are lower $\left(\sim 27.5^{\circ} \mathrm{C}\right)$, and rainfall more intense $(200-250 \mathrm{~mm})$.

\section{Catch per unit effort}

In BR, the pattern related to monthly CPUE in t/ fishing day was similar to that of monthly total catches,

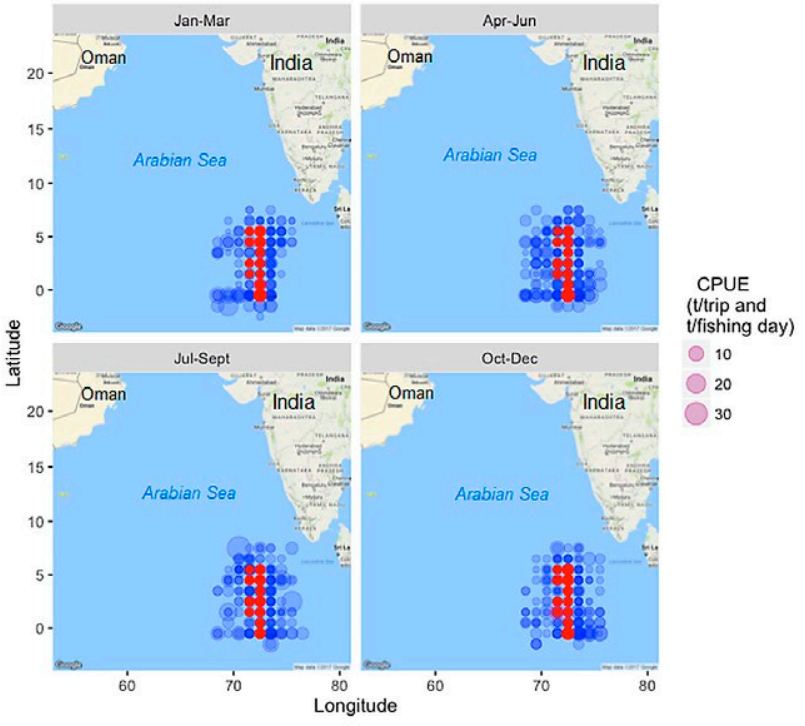

Fig. 10. - Quarterly maps of the total CPUE in the Maldives (units: in blue $t /$ fishing day; in red $t /$ trip).

i.e. lower values characterizing the winter period. In contrast, t/effective fishing day data showed considerable fluctuation.

The highest CPUE occurred in July (the austral winter). In the Maldives, the average CPUE in t/trip (which is usually equivalent to t/fishing days) varied slightly from month to month. It was somewhat higher during the months corresponding to the intermediate and northeast monsoon (Oct-Dec). The t/fishing day data highlight greater average CPUEs with few variations between April and September, partly corresponding to the summer monsoon (Jun-Sep). No significant correlation was found between monthly average CPUE (Spearman coefficient was in all cases around $10^{-1}$ ) for $\mathrm{BR}$ and MA.

\section{Space-time distribution}

Quarterly space-time distribution of skipjack fisheries CPUE in BR shows that from January to March higher CPUEs are concentrated at latitudes higher than $28^{\circ} \mathrm{S}$ and reach the mouth of the La Plata River (Fig. 9). Between April and June, the point cloud is narrower and shorter in its south and southeast sides, and seems

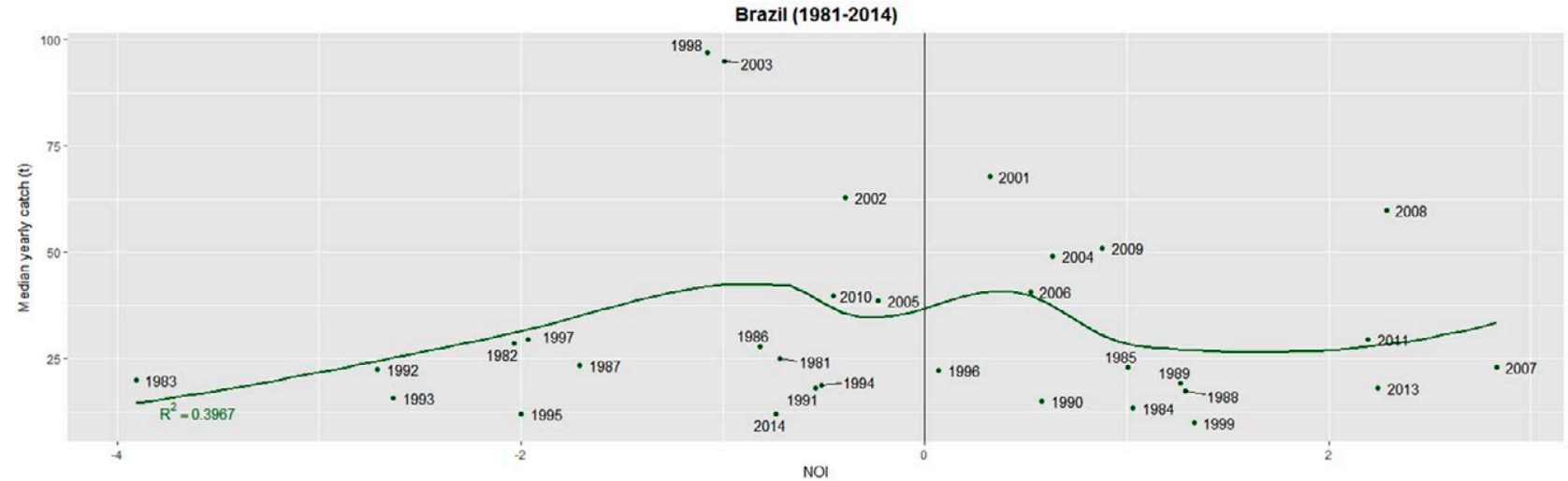

Fig. 11. - Median yearly skipjack catch in Brazil as a function of NOI signal, adjusted with a non-linear parametrized curve (rs=0.578*, p-value $=3.52 \mathrm{e}-4)$. 


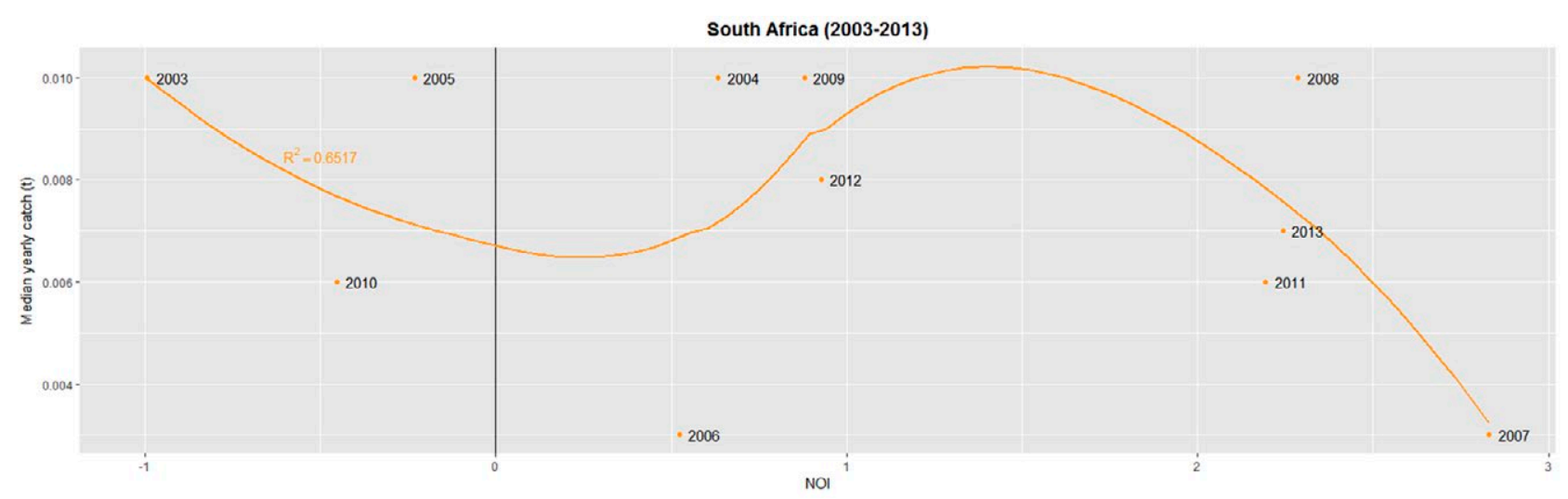

Fig. 12. - Median yearly skipjack catch in South Africa as a function of NOI signal, adjusted with a non-linear parametrized curve (rs=-0.799*, $\mathrm{p}$-value $=3.244 \mathrm{e}-7)$.

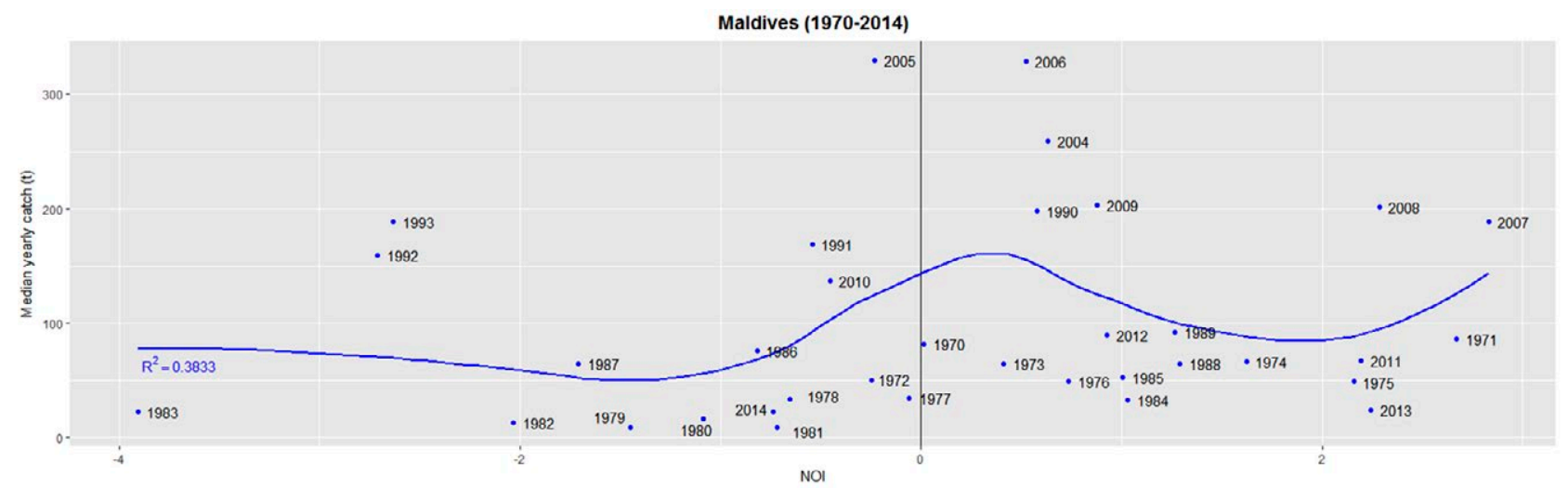

Fig. 13. - Median yearly skipjack catch in the Maldives as a function of NOI signal, adjusted with a non-linear parametrized curve (rs $=0.609^{*}$, $\mathrm{p}$-value $=0.141 \mathrm{e}-3$ ).

to grow northward. This tendency was accrued in winter, and reversed during the austral summer.

MA skipjack fisheries (Fig. 10) did not reveal a CPUE seasonal dynamic as clearly as happened off southeastern Brazil. The effort in MA computed in $\mathrm{t} /$ fishing day had a sparser geographic distribution than the effort computed in $\mathrm{t}$ /trip, irrespective of the season. The blue dots ( $\mathrm{t}$ /fishing days) show higher catches in the west of the atolls between April and September, while the same area was somewhat less productive from October to March. Between July and September, CPUE increased offshore the atolls, while between January and March the fishing events were concentrated mostly around the atolls.

\section{El Niño Southern Oscillation}

Figure 11 illustrates the variation of mean yearly catch as a function of the NOI for BR. The non-linear regression explained $40 \%$ of the yearly catch distribution pattern, suggesting that higher catches are associated with a NOI of -1 and 0.5 , while lower catches are associated with neutral years (NOI around 0 ). The years 1998 and 2003, well-known El Niño years, stand out with a higher skipjack production. Overall, the highest catches occurred within a NOI ranging from -1 to 1 . In SA (Fig. 12), $67 \%$ of the catch could be explained by the NOI, with lower catches occurring dur-
Table 2. - Spearman correlation coefficient calculated between median yearly catch ( $\mathrm{t}$ ) and NOI. The asterisk indicates significant correlation.

\begin{tabular}{cr}
\hline Median yearly catch & Spearman correlation with NOI \\
\hline Brazil & $\mathrm{rs}=0.578^{*} \mathrm{p}=3.510^{-4}$ \\
South Africa & $\mathrm{rs}=-0.799^{*} \mathrm{p}=3.2410^{-7}$ \\
Maldives & $\mathrm{rs}=0.609^{*} \mathrm{p}=1.410^{-4}$ \\
\hline
\end{tabular}

ing neutral years and a high NOI. The pattern observed for MA (Fig. 13) is similar to that of BR, with catches declining on both sides of the 0.5 NOI scale, following the adjusted non-linear regression. Interestingly, all three time series of median yearly catch were strongly correlated with the NOI signal (Table 2).

\section{DISCUSSION}

\section{Inter-annual analysis}

This study aimed to identify possible common trends between the skipjack fisheries, and to serve as a starting point for further comparative analyses of crossocean basin fisheries. Our results suggest a positive correlation between total skipjack catches in BR and SA, although many factors not taken into account here may influence catch. The common increasing trend may be linked to the overall development of the fisheries, and influenced by the considerable fluctuation of 
catch data (c.f. the low $\mathrm{R}^{2}$ found for the linear regression of BR catch time series), which can camouflage the status of the stocks (ICCAT 2014b). Additionally, different species of tuna can make up the so-called "mixed banks": in the southwest Atlantic Ocean, 5\% of the catch resulting from the effort directed towards skipjack tuna is composed of yellowfin tuna (Thunnus albacares) (Andrade et al. 2015), so the CPUE calculation can be biased. The data used for SA in the present study refer to incidental catch of the skipjack by the fleet targeting albacore, which explains the lack of effort data regarding SA skipjack catches. Nevertheless, the data highlight an increase in skipjack catches between 2003 and 2013, which corresponds with ICCAT (2014b) observations that skipjack catches in the eastern Atlantic have risen considerably between 2010 and 2013. In MA the opposite occurred, as emphasized by the significance of the negative correlation coefficients between SA and MA data. An abrupt decline in total catches occurred from 2006 to 2012, and was also observed for the Indian Ocean as a whole (IOTC 2010). According to Fonteneau (2003), the Indian Ocean is the second most productive ocean in terms of skipjack catches, reaching 0.4 million $\mathrm{t}$ as a result of 20 years of rising catches starting in the 1980s. This increase could be linked to the technological improvement of the fleet, as well as the development of Fish Aggregation Devices (FADs). More recently, the decrease in skipjack catches in the Maldives fishery until 2010 can be attributed to a number of factors, such as (i) an improvement in data collection; (ii) a new competition with handliners; and (iii) a reorientation of the effort targeting albacore (IOTC 2017). We show that this trend persisted for two years more. The strong association found between yearly catch and air temperature should also be interpreted under the light of these structural factors influencing the fishery productivity, since this result is not reflected in the seasonal analysis. However, the increasing temperature observed over the years may not only influence the behaviour of the resource itself (Arrizabalaga et al. 2014), but also the integrity of anglers' communities in the Maldives, one of the small-island developing states ranked among the most vulnerable countries in the face of climate change (Blasiak et al. 2017).

Although catches are declining, the increasing CPUE implies either a reduction in biomass or a simultaneous decrease in fishing effort. IOTC (2015), however, reports an increase in Maldivian fishing effort (which composed almost the totality of skipjack harvesting in WIO) over time, related to the development of mechanization within the fleet starting from 1974 , as well as the growing use of FADs (or Olivaal$i$ Kandhufathi in Maldivian). These devices can, among other consequences, decrease the time spent searching for the shoal, since the fishes are previously spotted. Andrade et al. (2007) argue that this change could be one source of error for the estimation of effort in 'fishing days', and therefore for the determination of CPUE, which consequently exhibits more noise, as verified in the present study. However, the findings of Medley et al. (2017) suggest that FADs are not a main source of variation among CPUE time series. This supports the possibility of comparing BR skipjack fishery, in which no FADs are used, with that of MA. Instead, 'other fish catch', 'atolls' and 'vessel length' stand out as primordial drivers of CPUE variation in the MA. The fact that we do not standardize the CPUE data in the present study might explain the difference from the results found by Medley et al. (2017) for MA skipjack CPUE, as well as skew the comparison among ocean basins, and this must be a primordial aspect to address in a further comparative study. Still, the plot obtained for CPUE in BR is similar to the one found by Meneses de Lima (2006) after a standardization of the CPUE through a generalized linear model.

With regard to the spatial catch and CPUE distributions off BR, a southward and offshore expansion over the decades is noticeable, mainly from the CPUE mapping between 2004 and 2010. This tendency indicates (i) a higher availability of the stock off the southern states of Brazil and (ii) a development in the fleet capacity over time, underlying the rising trend of the yearly catch. The increase in fishing power arising from the upgrade of the Brazilian skipjack fleet concerns mainly the national boats, which specialized their infrastructure. The technical improvements such as the installation of ponds for the live bait and lateral jet of water (Meneses de Lima et al. 2000), together with strong national subsidies (Abdallah and Sumaila 2007), fostered the development of an industrial skipjack fishery in Brazil. Skipjack catches from South Africa also show a movement towards the open ocean, but the data are limited and are for fleets targeting yellowfin. In contrast, the Maldivian skipjack fleet targets a similar area every year. This pattern is probably linked to FAD positioning, although the number of dots indicating skipjack fishing events (more than 72) does not match with the 45 FADs recorded by Shainee and Leira (2011). Over the years, the areas showing the highest fishing activity by this fleet follow the contours closer to the Maldivian islands, with catch and CPUE declining towards the open ocean.

\section{Seasonal analysis}

The evident seasonal trend in the monthly catch analysis in both Brazil and SA (lower catches in the austral winter and higher catches in summer) are supported by strong correlations within and between the studied regions. Indeed, from July to September (end of winter), the reduction in skipjack catches may explain the lack of skipjack catches off SA for this period. The results echo with those of Andrade (2003), who demonstrates that the seasonality of skipjack catches within the southwestern Atlantic Ocean is largely attributed to sea surface temperatures. A global rise in temperatures arising from climate change could therefore, in the short term at least, benefit skipjack fisheries production in BR and SA. However, unlike Andrade et al. (2005), who suggest that rainy days have negative effects on CPUE, we find that months with higher rainfall rates are strongly associated with higher skipjack production in Brazil. This discrepancy could be 
explained by the data used (logbooks and fishermen's indications for Andrade et al. 2005), but this relation should be further investigated. The Maldivian context is shaped by the monsoon climate: catches peak in June prior to the lower total monthly catches coinciding with the summer monsoon, confirming the results obtained by Koya et al. (2012). The weak association between monthly catches and climatic indicators may be linked to the presence of FADs, which to some extent guarantee skipjack availability, and the fishing ground is set in advance.

The same seasonal component defines the monthly CPUE variation in BR. Meneses de Lima (2006) links the typical weather conditions in winter, namely low temperatures, strong winds and rough seas, with a decrease in the occurrence and/or success of a fishing event (unsuccessful fishing days account for $49.2 \%$ of the total in July, whereas in January this percentage typically drops down to $11.9 \%$ ). In contrast, in MA, the monthly CPUE does not indicate a seasonal pattern as it does in BR. If the influence of FADs on CPUE has not been considered in this study, neither was a consensus found in the literature on a seasonal pattern in skipjack abundance in MA.

The spatiotemporal catch and CPUE distribution off southeastern Brazil confirmed the results of Andrade (2003) and Meneses de Lima (2006). CPUE north and southward longitudinal movement is correlated with summer and winter, respectively. Around the Maldives, the results obtained match with those of Yesaki and Waheed (1992), who noted a displacement northward from May onwards (summer monsoon), and southward from November onwards (winter monsoon). Seasonal CPUE mapping suggests little west-east movement. Similarly, Wang et al. (2014) found that seasonal variations in the longitudinal gravitational centre of skipjack catch in the Pacific is higher during El Niño events and for free schools (unlike FAD associated schools). However, since Govinden et al. (2013) conclude that the longest time skipjacks spend associated with FADs is 12.8 days in January, compared with no longer than 1 day November, although the presence of FADs likely influences skipjack movements, some seasonal and spatial variations in the stock abundance should be further observable, which was not the case in the present study. Thus, these variations are intrinsically linked to the environmental oscillations and the use of FADs.

The comparison between Maldivian and Brazilian skipjack population dynamics is hampered by the very different climate and currents regimes prevailing in each region, while SA climate conditions are closer to those of BR. Castello and Habiaga (1989) stated that seasonal skipjack distribution varies with the seasonal behaviour of the Subtropical Convergence off BR. Similarly, in the Indian Ocean, a second-although contested-explanation for the monsoon phenomena is linked with a seasonal migration of the Intertropical Convergence Zone (ITCZ) (Gadgil 2003). Thus, if we find (i) a relation between skipjack seasonal displacements and the monsoon climate and (ii) an association between the monsoon dynamics and the ITCZ regu- latory mechanisms, then we might hypothesize that skipjack movements could be influenced by the ITCZ migration pattern.

\section{El Niño Southern Oscillation}

Our findings reveal a strong correlation between the NOI and the yearly catch time series for the three study areas. However, as only catch data and not CPUE were used, the highest catches in Brazil noticeably occur in more recent years, while catch related to the early stages of this fishery is located on the graph below the adjusted curve. The higher $R^{2}$ found for the SA curve can be interpreted in light of the incidental nature of these skipjack catch data (bycatch of the SA tuna fleet). As a result, the quantitative oscillations of the catch reflect more directly the abundance and occurrence of the resource. Indeed, landings declined with an increase in the NOI, similarly to the findings of Ormaza-González et al. (2016). Without the use of ENSO indexes, the different attributes of which are not discussed here, Hafiz and Anderson (1994) found that abrupt drops in skipjack catches by the Maldivian fleet were correlated with El Niño years. This pattern was also evident in our study, albeit for only some El Niño events. This finding implies that the effect of ENSO events on catches may be inconsistent, as already suggested by Hafiz and Anderson (1994). Furthermore, we did not consider the time lag between the occurrence of El Niño events and the resultant impact on skipjack habitats. This aspect could also, in addition to the climatic indices, interconnected hydrodynamic characteristics or teleconnections, often influence fishing patterns and the relative abundance of skipjack stocks found in the study regions.

This study primarily aims to improve our understanding of the links between climate variability and skipjack fisheries from a cross-ocean basins approach. We find strong similarities between Brazilian and South African skipjack catches, as well as between their responses to air temperature and rainfall seasonal conditions. Although interesting associations with the Maldivian skipjack production were also found, the predominance of the monsoon climate and intense use of FADs should be considered in further analyses. Similarities in catch and spatial distribution of skipjack as a fishing resource do exist between southern regions of the globe, and inter-comparative analysis is key for depicting which and how global factors affect production. The roles of ICCAT and IOTC in managing tuna and tuna-like species in the Atlantic and Indian Ocean, gathering, analysing and making available the data for the relevant fishery, are crucial. However, this study calls for further inter-oceans investigations and dialogue at the southern latitude level, through South-South cooperation and cooperation between tuna regional fisheries management organizations (tRFMOs), in order to face the common key challenges of the fishing sector of emerging countries, ever more compromised in the context of global warming. 


\section{ACKNOWLEDGEMENTS}

We thank Ms. Cindy Sidina from the South African Department of Agriculture, Forestry and Fisheries for the local data access, and Tito Conte and Martim Mas for helping in the map production. We are grateful to the editors and reviewers, and to Dr. Gorka Merino for the valuable suggestions. Thanks to the University of São Paulo's Oceanographic Institute and the Fisheries Ecosystems Laboratory (LabPesq) for hosting this study, and to the Belmont Forum Initiative and FAPESP (São Paulo Research Foundation, Project 2012/51873-1) and the National Science Foundation for supporting the GULLS Project in both Brazil and South Africa. M.A.G. thanks the Brazilian National Research Council (CNPq) for the productivity grant.

\section{REFERENCES}

Abdallah P.R., Sumaila U. 2007. An historical account of Brazilian Public Policy on Fisheries Subsidies. Mar. Pol. 31: 444-450. https://doi.org/10.1016/j.marpol.2007.01.002

Adam M.S., Sibert J.R. 2002. Population dynamics and movements of skipjack tuna (Katsuwonus pelamis) in the Maldivian fishery: analysis of tagging data from an advection-diffusion-reaction model. Aquat. Living Resour. 15: 13-23. https://doi.org/10.1016/S0990-7440(02)01155-5

Allison E.H., Perry A.L., Badjeck M-C., et al. 2009. Vulnerability of national economies to the impacts of climate change on fisheries. Fish. Fish. 10: 173-196. https://doi.org/10.1111/j.1467-2979.2008.00310.x

Andrade H.A. 2003. The relationship between the skipjack tuna (Katsuwonus pelamis) fishery and seasonal temperature variability in the South-Western Atlantic. Fish. Oceanogr. 12: 10-18. https://doi.org/10.1046/j.1365-2419.2003.00220.x

Andrade H.A., Tozetto A.L., Santos J.A.T. 2005. The effect of environmental factors and of the fishermen strategy on the Skipjack tuna (Katsuwonus pelamis) CPUE in the Southwest Atlantic. Col. Vol. Sci. Pap. ICCAT 58: 350-358.

Andrade H.A., Pereira M.D., Mayer F.P. 2007. Alternative methods for calculating catch-per-unit-effort for skipjack tuna (Katsuwonus pelamis) caught in the Southwestern Atlantic Ocean. Braz. J. Aquat. Sci. Technol. 11: 63-66. https://doi.org/10.14210/bjast.v11n2.p63-66

Andrade H.A., Guimarães-Silva A.A., Batista C.H.O. 2015. Catch composition of the baitboat fishery in the Southwestern Atlantic. Col. Vol. Sci. Pap. ICCAT 71: 317-324.

Arrizabalaga H., Dufour F., Kell L., et al. 2014. Global habitat preferences of commercial valuable tuna. Deep Sea Res. Part II: Top. Stud. Oceanogr. 113: 102-112. https://doi.org/10.1016/j.dsr2.2014.07.001

Belhabib D., Mendy A., Subah Y. et al. 2016. Fisheries catch underreporting in The Gambia, Liberia and Namibia, and the three Large Marine Ecosystems which they represent. Environ. Dev. 17: 157-174. https://doi.org/10.1016/j.envdev.2015.08.004

Blasiak R., Spijkers J., Tokunaga K., et al. 2017. Climate change and marine fisheries: developed countries top global index of vulnerability. PLoS ONE 12: e0179632. https://doi.org/10.1371/journal.pone.0179632

Campos E.J.D., Miller J.L., Müller T.J., et al. 1995. Physical Oceanography of the Southwest Atlantic Ocean. Oceanography 8: 87-91. https://doi.org/10.5670/oceanog.1995.03

Castello J.P., Habiaga R.P. 1989. The skipjack fishery in Southern Brazil. Col. Vol. Sci. Pap. ICCAT 30: 6-19.

Cushing D.H. 1975. Marine ecology and fisheries. Cambridge Univ. Press, Cambridge, 278 pp.

Dong B., Sutton R.T., Scaife A.A. 2006. Multidecadal modulation of El Niño-Southern Oscillation (ENSO) variance by Atlantic Ocean sea surface temperatures. Geophys. Res. Lett. 33: L08705.

https://doi.org/10.1029/2006GL025766

Dueri S., Bopp L., Maury O. 2014. Projecting the impacts of climate change on skipjack tuna abundance and spatial distribution.
Glob. Change Biol. 20: 742-753.

https://doi.org/10.1111/gcb.12460

Fonteneau A. 1986. Eléments relatifs à l'Effort de Pêche exercé sur le Listao de l'Atlantique (Katsuwonus pelamis) et Calcul d'Indices d'Effort Spécifiques. In: Proceedings of the ICCAT conference on the international skipjack year program: 21-29 Jun 1983, Tenerife, Spain. ICCAT, Madrid, pp. 127-139.

Fonteneau A. 2003. A comparative overview of skipjack fisheries and stocks worldwide. In: Proceedings of the 16th Meeting of the Standing Committee on Tuna and Billfish, 9-16 July 2003. Mooloolaba, Australia. SPC, Noumea, 15 pp.

Gadgil S. 2003. The Indian monsoon and its variability. Annu. Rev. Earth Planet. Sci. 31: 429-467. https://doi.org/10.1146/annurev.earth.31.100901.141251

Govinden R., Jauhary R., Filmalter J., et al. 2013. Movement behavior of skipjack (Katsuwonus pelamis) and yellowfin (Thunnus albacares) tuna at anchored fish aggregating devices (FADs), in the Maldives, investigated by acoustic telemetry. Aquat. Living Resour. 26: 69-77. https://doi.org/10.1051/alr/2012022

Hafiz A., Anderson R.C. 1994. The Maldivian tuna fishery - an update. In: Proceedings of the 5th Expert Consultation on Indian Ocean Tunas: 4-8 Oct 1993, Malé, Seychelles. ITPT, Colombo, pp. 30-33.

International Commission for the Conservation of Atlantic Tunas (ICCAT). 2014a. Task II - Catch \& Effort (T2CE). [Database on the Internet]: ICCAT. http://www.iccat.org/en/t2ce.asp

International Commission for the Conservation of Atlantic Tunas (ICCAT). 2014b. Report of the 2014 ICCAT East and West Atlantic Skipjack stock assessment meeting: 23 Jun - 1 Jul 2014, Dakar, Senegal. ICCAT, Madrid, 98 pp.

International Commission for the Conservation of Atlantic Tunas (ICCAT). 2017. Report of the 2017 Standing Committee on Research and Statistics (SCRS): 2-6 Oct 2017, Madrid, Spain. ICCAT, Madrid, 465 pp.

Indian Ocean Tuna Commission (IOTC). 2010. Declining catches of Skipjack in the Indian Ocean - Observations from the Maldives. Document from the 12th Meeting of the Working Party on Tropical Tunas (WPTT): 18-25 Oct 2010, Victoria, Seychelles. IOTC, Victoria, 2 pp.

Indian Ocean Tuna Commission (IOTC). 2015. Résumé de l'état des thons et des espèces apparentées sous mandat de la CTOI, ainsi que des espèces affectées par les pêcheries de la CTOI. [S1.]: IOTC. http://www iotc.org/fr/science/résumé-de-létat-des-stocks

Indian Ocean Tuna Commission (IOTC). 2016. IOTC-2016-DATASETS-CESurface. [Database on the Internet]: IOTC. http://iotc.org/documents/ce-purse-seine-and-bait-boat

Indian Ocean Tuna Commission (IOTC). 2017. Review of the statistical data and fishery trends for tropical tunas. Document from the 19th Meeting of the Working Party on Tropical Tunas (WPTT): 17-22 Oct 2017, Mahé, Seychelles. IOTC, Victoria, $47 \mathrm{pp}$.

International Seafood Sustainability Foundation (ISSF). 2018. Status of the world fisheries for tuna. ISSF Tech Rep 2018-02. International Seafood Sustainability Foundation, Washington, $101 \mathrm{pp}$.

Kahle D., Wickham H. 2013. Ggmap: Spatial Visualization with ggplot2. The R J. 5: 144-161.

Kumar P.S., Pillai G.N., Majusha U. 2014. El Nino Southern Oscillation (ENSO) impact on tuna fisheries in Indian Ocean. SpringerPlus 3: 591. https://doi.org/10.1186/2193-1801-3-591

Koya K.P.S., Joshi K.K., Abdussamad E.M., et al. 2012. Fishery, biology and stock structure of skipjack tuna, Katsuwonus pelamis (Linnaeus, 1758) exploited from Indian waters. Indian J. Fish. 59: 39-47.

Legendre P., Oksanen K., ter Braak C.J.F. 2011. Testing the significance of canonical axes in redundancy analysis. Methods Ecol. Evol. 2: 269-277. https://doi.org/10.1111/j.2041-210X.2010.00078.x

McIlroy D. 2015. Packaged for R by Ray Brownrigg, Thomas P Minka and transition to Plan 9 codebase by Roger Bivand. mapproj: Map Projections. R package version 1.2-4. https://CRAN.R-project.org/package=mapproj

Medley P.A.H., Ahusan M., Adam M.S. 2017. Bayesian CPUE Standardization Model for Maldives Pole and Line Skipjack Tuna 1970-2015. Document from the 19th Working Party on Tropical Tunas (WPTT). 17-22 Oct 2017, Mahé, Seychelles. 
IOTC, Victoria, $7 \mathrm{pp}$.

Ménard F., Fonteneau A., Gaertner D., et al. 2000. Exploitation of small tunas by a purse-seine fishery with fish aggregating devices and their feeding ecology in an eastern tropical Atlantic ecosystem. ICES J. Mar. Sci. 57: 525-530. https://doi.org/10.1006/jmsc.2000.0717

Meneses de Lima J.H. 2006. Padronização do índice de abundância e avaliação do estoque de bonito listrado, (Katsuwonus pelamis Linnaeus, 1758), do Atlântico Ocidental. Ph.D. thesis. São Carlos University, São Carlos, 214 pp.

Meneses de Lima J.H., Lin C.F., Menezes A.A.S. 2000. As pescarias brasileiras de bonito-listrado com vara e isca-viva, no Sudeste e Sul do Brasil, no perodo de 1980 a 1998. Bol. Téc. Cient. Tamandaré 8: 7-99.

Ministry of Fisheries and Agriculture (MoFA). 2013. Maldives National Report submitted to the Scientific Committee of the Indian Ocean Tuna Commission. Ministry of Fisheries and Agriculture, Malé, $15 \mathrm{pp}$.

Ministry of Planning, Human Resources and Environment (MPHRE). 2016. Statistical year book of Maldives 2016. Ministry of Planning, Human Resources and Environment, Malé, Republic of Maldives.

Nicholson S.E. 1997. An analysis of the ENSO signal in the Tropical Atlantic and Western Indian Oceans. Int. J. Climatol. 17: 345-375.

h t t p s: // d o i.org/10.1002/( S I C I ) 1097 . 0088(19970330)17:4<345::AID-JOC1273.0.CO;2-3
Ormaza-González F.I., Mora-Cervetto A., Bermúdez-Martínez R.M. 2016. Relationship between tuna catch and variable frequency oceanographic conditions. Adv. Geosc. 42: 83-90. https://doi.org/10.5194/adgeo-42-83-2016

Popova E., Yool A., Byfield V., et al. 2016. From global to regional and back again: common climate stressors of marine ecosystems relevant for adaptation across five ocean warming hotspots. Glob. Change Biol. 22: 2038-2053. https://doi.org/10.1111/gcb.13247

Ricker W.E. 1954. Stock and recruitment. J. Fish. Res. Board Can. 11: 559-623. https://doi.org/10.1139/f54-039

Schwing F.B., Murphree T., Green P.M. 2002. The Northern Oscillation Index (NOI): a new climate index for the northeast Pacific. Prog Oceanogr. 53: 115-139. https://doi.org/10.1016/S0079-6611(02)00027-7

Shainee M., Leira B.J. 2011. On the cause of premature FAD loss in the Maldives. Fish. Res. 109: 42-53. https://doi.org/10.1016/j.fishres.2011.01.015

Wang X., Chen Y., Truesdell S., et al. 2014. The Large-Scale Deployment of Fish Aggregation Devices Alters EnvironmentallyBased Migratory Behavior of Skipjack Tuna in the Western Pacific Ocean. PLoS ONE 9: e98226. https://doi.org/10.1371/journal.pone.0098226

Yesaki M., Waheed A. 1992. Results of the tuna tagging programme conducted in the Maldives during 1990. Indo-Pacific Tuna Development and Management Programme. FAO-UNDP, 23 pp. 